\title{
BOSNIAN MODEL OF DEMOCRATIC AUTHORITY: CONDI- TION FOR STABILIZATION OF BOSNIA AND HERZEGOVINA?
}

\section{Dženeta Omerdić ${ }^{1}$}

Faculty of Law, University of Tuzla

Received: 18.02 .2016

Accepted: 21.03.2016

\author{
Original scientific paper
}

UDC: $371.72: 342.2(497.6)$

321.01(497.6)

323(4976)

\begin{abstract}
The principle of non-discrimination in modern legal systems, both at national and at regional and global levels of government, is the primary prerequisite for the realization of all other (fundamental) rights and freedoms. The essence of this principle, which is, in fact, inextricably linked to the principle of equality in rights, is reflected in the requirement to ensure to all persons, without discrimination on any basis, the realization and enjoyment of the fundamental rights and freedoms that are guaranteed by provisions of the national constitutions, Laws and other legal acts. The functionality of the entire state government of Bosnia and Herzegovina is often hindered by the complex decision-making processes at all state levels which lead to obstruction of the entire decision-making process. Such a disfunctional decision-making process on the state level poses a threat and disables the Bosnian plural society to respond to the modern challenges of a democratic functioning state. The Bosnian model of democratic authority is trying to determine the individual primarily as a citizen, to which they bind certain rights and duties, but without neglecting the fact that citizens enjoy certain rights (and obligations) that belong to them based on their affiliation to a particular collectivity. Bosnian society as a community of citizens and a community of communities should not ignore any of the aforementioned sides of human nature. Key words: plural society, democracy, Bosnia and Herzegovina, consociational democracy, Bosnian model of democratic autohority, citizen
\end{abstract}

\section{INTRODUCTION}

Before the socio-political communities are posted, a very demanding task of defining the subject on whose name will behalf political power is implemented over a given state territory. However, the question about the subject of sovereignty should in no case be misunderstood as an issue of simply theoretical approach, primarily because its significance is extremely relevant to "the democratic foundation of the overall constitutional and social order" (Trnka, 2006, p. 173). Moreover, to isolate the key factors that influence the establishment of state in- stitutions and their mutual relations, the processes of globalization, as well as a contemporary social phenomena's, states are obliged to define and implement the constitutional and legal position of the individual and its "relationship" with subject of sovereignty.

All citizens should be able to express and affirm themselves in all spheres of social (and individual) life. So, the main task of the state's organizational form is to create such conditions that will enable every individual to convey it as a citizen.

\footnotetext{
${ }^{\mathbf{1} C o r r e s p o n d e n c e}$ to:

Dzeneta Omerdic, PhD, Faculty of Law, University of Tuzla

Phone: +38735250658

e-mail: dzeneta.omerdic@untz.ba
} 
In order to determine the state as a civil and democratic, it is necessary to provide each citizen with the following: a) create and "live his intimate world "(Mirić, 1996, p. 51); b) being involved in numerous community organizations, institutions, associations and other professional groups, and c) enjoy the fundamental rights and freedoms.

During the entire period of its existence, Bosnia and Herzegovina has been the subject of numerous discussions. Several discussions focused on the origin of the name of Bosnia and Herzegovina, some discussions were about religious affiliation of its population, or, in turn, discussions about Bosnian internal state's organization and the legal nature of state's regime. However, one question aroused immense curiosity among the general public, as the following: "Is Bosnia and Herzegovina an asymmetric consociational society or is a complex Bosnian democratic system consequence of merely a mesh of (un) fortunate circumstances?"

Based on the thesis that Bosnia and Herzegovina is a "paradigmatic plural or deeply divided society" (Kasapović, 2005, p. 77), advocates of the theory of consociational democracy point out that the only way for subsistence of $\mathrm{B} \& \mathrm{H}$ as a integral and functional country is an application of the principle of consociation and consistent implementation of its fundamental principles, primarily the principle of territorial segmentation of Bosnian society. However, at this point it is necessary to reflect on certain issues related to the plurality of Bosnian society:

1. Does Bosnian society represent a historically deeply divided society, or is this just a myth originated with intent to justify the aggression against $\mathrm{B} \& \mathrm{H} ?^{2}$

2. On what basis is the Bosnian society currently deeply divided?

3. What are the different levels of such deep division within the Bosnian society?

\footnotetext{
${ }^{2}$ In the period from 1992 to 1995 in Bosnia and Herzegovina was not a civil war, as explicitly stated Mirjana Kasapović, because there was no internal war between the three ethnic groups, nor is there a conflict between the state government and rebel sides. During this period there was an aggression against independent state of Bosnia and Herzegovina. That was in such form as the term of aggression is defined in the art. 1 of The Resolution of UN General Assembly of 14 December 1974: "Aggression is the use of armed force by a State against the sovereignty, territorial integrity or political independence of another State, or in any other manner inconsistent with the Charter of the United Nations, as set out in this Definition". See more: Ibrahimagić, Omer, BOSNA JE ODBRANJENA ALI NIJE OSLOBOĐENA, Vijeće kongresa bošnjačkih intelektualaca, Sarajevo, 2004. p. 134-138.
}

\section{BOSNIA AND HERZEGOVINA AS A PLURAL- ISTIC SOCIETY}

Historically, Bosnia and Herzegovina's society has never been deeply divided. Since its first mention in 949 ("De administrando imperio" of Constantine VII Porphyrogenitus) until today, in addition to its geopolitical and territorial integrity and a special state status, Bosnia and Herzegovina has managed to keep several important characteristics that have marked its state-legal development during all these centuries. This specific idea of multiculturalism, centuriesold tradition of common life of its residents who are professing different religions; cultivate different cultures, traditions and customs (Trnka, 2006, p. 79) has been nurtured for many centuries. Guided by the principle: "Live together with each other, not next to each other", Bosnians, regardless of whether they are Manicheans (followers of the teachings of the Bosnian Church), Muslims (after 1463), the Orthodox and Catholics, have never caused conflicts and wars that have occurred on this region. The causes were always found in hidden (?) interests and/or pretensions that came outside the territorial borders of Bosnia and Herzegovina.

On the territory of Bosnia and Herzegovina has never been an "age-old ethnic resentment", and as such could not be the primary basis for segmentation of Bosnian society and creation of a distorted image of B\&H as a "divided society and an unstable state." The main causes for the segmentation of Bosnian society, both in territorial and non-territorial sense, should be sought in the aggression against Bosnia and Herzegovina, as well as in the evident ideas of creating a "Greater Serbia" or "Greater Croatia" at the expense of Bosnian territory.

As claimed by Noel Malcolm, it is indisputable that in the past of Bosnia and Herzegovina was a fertile ground for "hatred and hostility", however, they were not "absolute or immutable, nor were the inevitable consequence of intermingling of different religious communities. The main basis of hostility was neither ethnic nor religious but economic: resentment came mostly from (but not exclusively) Christian peasants towards their Muslim landlords." (Malcolm, 1995: XXII-XXIII). Balkan region is characterized by many things, but the particularities that separate this region from the other parts of the world are certain national histories, for which some authors claim that they represent Balkan's curse. 
Namely, in the Balkans, as Malcolm stresses, there is no "ethnically homogeneous province, let alone nationally homogeneous country" (Malcolm, 1995, p.3). Furthermore, social gaps in Bosnian society were not caused by religion or ethnicity but rather by the aggression against Bosnia and Herzegovina. The basis of segmentation of Bosnian society can hardly be found in completely different separate cultures, due to the fact that a "superficial insight into the building blocks of culture" (Mujkic, 2006, p. 116) - language, history, art, tradition and others - illustrates that it is impossible to speak of separate history of Bosniaks, Bosnian Serbs and Bosnian Croats.

Artificial segmentation of Bosnian society largely favors the nationalistic political parties (or "elite segments of society), as well as their political programs that further deepen cleavages among the social segments in order to create the most favorable climate for satisfying the interests of the most privileged social representatives, moreover, with the far-reaching goals trying to prove that $\mathrm{B} \& \mathrm{H}$ is not possible either as integral society, nor as an integral and functional state. The political traditions, as well as Bosnian history indicate the existence of civil and consociational elements within the society of Bosnia and Herzegovina. However, currently the "balance of power" between these forms of democratic authority does not contribute to Bosnia and Herzegovina, as well as her citizens. As a result of domination of the elements of consociational democratic authority in the XXI century when the human rights and freedoms reached its peak, some of the most fundamental human rights in $\mathrm{B} \& \mathrm{H}$ are continuously violated: the active and passive voting rights. The citizens of $\mathrm{B} \& \mathrm{H}$, depending on their "constitutive affiliation" have the opportunity to enjoy both costs and benefits of their aforementioned rights and freedoms. In Bosnian case, constitutional provisions do not constitute consistent guardians of state and the entire Bosnian society, but largely make it possible for disintegrating factors to reach their peak.

\section{BOSNIAN MODEL OF DEMOCRATIC AU- THORITY - CONDITION FOR STABILIZA- TION OF BOSNIA AND HERZEGOVINA}

The functionality of the entire state government is often hindered by the complex decision-making processes at all state levels which lead to obstruction of the entire decision-making process. Such a disfunctional decision-making process on the state level poses a threat and disables the Bosnian plural society to respond to the modern challenges of a democratic functioning state. There is still no end in sight to the struggle that leads to oligarchy of the ruling elites; furthermore there is still no appropriate socio-political mechanism that will enhance the accountability of the representatives to their voters; it is still inconceivable that decisions of state authorities are effectively and consistently implemented throughout the national territory.

According to the tradition and political culture of Bosnia and Herzegovina, "pure" model of consociational democracy and "pure" bourgeois democracy model do not correspond with the social being of $\mathrm{B} \& \mathrm{H}$ and the Bosnian society. "Pure" models do not lead Bosnia and Herzegovina to integration into European Union. Elite coalitions of certain social's segments, among which stand out primarily national, do not encourage the creation of integral and functional state policy that would satisfy the criteria of an individual civil-political participation. On the other hand, the electoral process is carried out in an ethnically homogeneous areas and it transforms from individual to exclusively ethnic representation of interests, submitting and ignoring the interests of minority ethnic groups (Reilly, 2002). The abuse of the veto right and the protection of vital national interests have become a major obstacle in the social and state developments, as well as development of certain social groups.

It is necessary to "offer" Bosnia and Herzegovina's pluralism and its political tradition a form of democratic authority which in no way should be a cliché. Furthermore, it may not be one of the "copy-paste" models of democratic authority. Currently, citizens of $\mathrm{B} \& \mathrm{H}$ are completely suspended (there are only citizens of entities). In the Federation of Bosnia and Herzegovina Serbs are suspended, while in the Republica Srpska, Bosniaks and Croats cannot equally participate in the decision-making process. Namely, in the House of Peoples of the Parliamentary Assembly of B\&H, Bosniaks and Croats from the Republika Srpska, as well as the Serbs from FB\&H cannot participate in the legislative process. They cannot be members of this state's legislative authority. In our opinion, if elected political decision-makers want to establish such a society in which individuals and collectives are completely respected in a modern state in which individual and collective rights, interests and freedoms are fully protected, it is necessary to establish a new functional model of democratic authority. Therefore, we suggest the use of a specific Bosnian model of democratic authority. 
The Bosnian model of democratic authority would include all the citizens of B\&H, Bosniaks, Bosnian Croats and Bosnian Serbs in the decision-making process, representing a civil-consociational democratic form of authority and it would be reflected in the following: the primacy of the individual in relation to the various collectivities, without prejudice and without diminishing thereby the importance of collective rights and interests; depoliticization of the religion; instead of the mono-ethnic political party, multi-ethnic parties, or coalitions (Ibrahimagić, 2008) should constitute the framework for the development and stability of Bosnian society. This would prevent further ghettoization of members of different ethnic and confessional groups; domination of multi-ethnic parties or coalitions (parties of bourgeois provenance) enables "the interethnic accommodation", and representation of civil (political representation), ethnic (proportional or parity representation) and the minority principle (minimum representation of national minorities) at all levels of governance.

The future of Bosnia and Herzegovina is certainly not in the primacy of the collectivities under the citizens (individuals), nor does the institutionalization of collective identity represent a guarantee of stability and prosperity of B\&H society. On the contrary, Bosnia and Herzegovina should use the example and experience of Switzerland. More specifically, the Swiss constitution-makers avoided any possibility of deep and sharp social cleavages between members of different religious groups (Bohn, 2005; Stojanović, 2007). According to the Swiss Constitutional provisions Catholics have not been constituted (Catholics are not recognized as a constitutional category).

However, it would be unacceptable if Bosnia and Herzegovina were to be denounced of its multi-ethnic and multi-religious identity in the future. Denying Bosnian pluralism would lead $\mathrm{B} \& \mathrm{H}$ in an undesirable direction: new conflicts between "social segments" and strengthening of centrifugal forces which, unfortunately, still have a significant role on B\&H political scene. Furthermore, the future and stability of Bosnian society lies in the process of recognition of all ethnic communities and their mutual "reconciliations". In order to achieve the aforementioned, it is essential to align the provisions of the Dayton Peace Agreement with the provisions and principles of the international legal order. It is necessary to begin to apply international conven- tions, which are part of our constitutional order, and allow them to become guides that will facilitate the path of Bosnian society towards a European future $^{3}$ (Miraščić, 2012). Excellent suggestion, which is embedded in our theoretical Bosnian model of democratic authority, we find in an article by Ugo Vlaisavljevic who proposes depoliticization of religion, stressing that "religion can fulfill its positive political role only if it allows itself an undoubtedly degree of depoliticization. Its political abuse has become evident and it seems that it should withdraw from the political arena for the benefit of religion and politics together. "(Vlaisavljević, 2006, p. 238). The European future of B\&H could hardly be conceivable by domination of mono-ethnic political parties -which are assigned important roles in the $\mathrm{B} \& \mathrm{H}$ political scene and whose political programs are successful, only because they are directed against members of other ethnic groups and their interests. It is impossible to achieve the basic democratic principles: freedom and equality of all members of Bosnian society if mono-ethnic political parties are the most important "players" in the decision-making process.

${ }^{3}$ According to Annex I of the Constitution of $\mathrm{B} \& \mathrm{H}$, additional Human Rights Agreements that be applied in Bosnia and Herzegovina: 1. The Convention on the Prevention and Punishment of the Crime of Genocide (1948); 2. Geneva Conventions I-IV on the Protection of War Victims (1949) and the Additional Protocols (1977); 3. Convention relating to the Status of Refugees (1951) and Protocol (1966); 4. The Convention on the Nationality of Married Women (1957); 5. Convention on the Reduction of Statelessness (1961); 6. International Convention on the Elimination of All Forms of Racial Discrimination (1965); 7. International Covenant on Civil and Political Rights (1966) and Optional Protocols (1966 and 1989); 8. International Covenant on Economic, Social and Cultural Rights (1966); 9. Convention on the Elimination of All Forms of Discrimination against married women (1979); 10. Convention against Torture and Other Cruel, Inhuman or Degrading Treatment or Punishment (1984); 11. European Convention for the Prevention of Torture and Inhuman or Degrading Treatment or Punishment (1987); 12. The Convention on the Rights of the Child (1989); 13. International Convention on the Protection of the Rights of All Migrant Workers and Members of their Families (1990); 14. The European Charter for Regional or Minority Languages (1992), and 15 the Framework Convention for the Protection of National Minorities (1994). 


\section{WHAT IS MEANT BY BOSNIAN MODEL OF DEMOCRATIC AUTHORITY?}

"Otherness" and "Diversity" are deeply embedded in the B\&H society since the time of its existence. Therefore, the basis of modern civil society of $\mathrm{B} \& \mathrm{H}$, according to the Bosnian model of democratic authority, should form a multi-ethnic party or a coalition of civic provenance, whose political programs will fail due to exclusive intolerance towards others, even if the basis of their political platforms will represent the ideas of territorialization of ethnic segments in B\&H. In fact, multi-ethnic parties or coalitions (Ibrahimagić, 2008) could largely contribute to interethnic accommodation, in such a way so that no ethnic group would feel inferior to others, nor should any of the existing ethnic groups feel superior to others.

Suspending the Serbs in the Federation of B\&H and Bosniaks and Croats in Republika Srpska (in the decision-making process "the Others" are completely invisible and marginalized) leads to a situation where at the state level civil or consociational model of democratic authority is not achieved. Therefore, the Bosnian model of democratic authority should include all citizens of $\mathrm{B} \& \mathrm{H}$, as well as all existing Bosnian "social segments" (Miraščić, 2009).

The Bosnian model of democratic authority implies that at all levels: municipal, cantonal, entity, state level, should apply the following principles: the principle of civic participation; the principle of ethnic representation, and the principle of minority representation.

The principle of civic representation would imply a consistent application of the principle of "one citizen - one vote", which would be manifested in the process of forming municipal, cantonal, entities and state authorities. Application of civil (political) principles at the national level would include the necessity of forming multiple election constituencies throughout the country, which would be "formed" independent of the existing entity borders (Miraščić, 2009).

The application of the ethnic principle (proportional or parity representation) would allow equal representation of all three ethnic communities, to prevent domination by the majority collectivity in a certain administrative-territorial unit. Proportional or parity representation, followed by the right of veto and other consociational elements applied to all levels of government, would allow elimination of consequences of aggression, while at the same time preventing any form of domination by the war created majority. In this way, all members of Bosnian "social segments" will get the opportunity to be involved in $\mathrm{B} \& \mathrm{H}$ political life and decision-making processes.

The principle of minority representation and its application would enable national minorities and "the Others" to legitimately represent their political/ethnic interests at all state levels. In this way, the representatives of national minorities would again be included in the political "life" of Bosnia and Herzegovina, and would confirm the multi-ethnic and multi-confessional nature of $\mathrm{B} \& \mathrm{H}$, as well as a centuries long tradition of living together, regardless of ethnic, confessional or any other affiliation of Bosnian citizens.

Bosnian model of democratic authority, which is described as a civil-consociational model, does not provide the domination of any single "social segment", nor any form of majorization. Bosnian model, designed on historical facts, traditions and experiences of b\&h political society and the necessity for a speedy "inclusion" into the European mainstream seeks to reconcile the two sides of human nature: individual and collective. Individual "domination" in the Bosnian model, allows and respects mutual differences and enables the exercise of collective rights (not limited to those arising from ethnic or religious affiliation). The Bosnian model of democratic authority is trying to determine the individual primarily as a citizen, to which they bind certain rights and duties, but without neglecting the fact that citizens enjoy certain rights (and obligations) that belong to them based on their affiliation to a particular collectivity (Miraščić, 2009). Bosnian society as a community of citizens and a community of communities should not ignore any of the aforementioned sides of human nature. The current constitutional order, in addition to being directed against the fundamental principles of the international law, returning $\mathrm{B} \& \mathrm{H}$ society in the period of the rule of the few (oligarchy), creates an atmosphere in which "constitutive people" are superior among "the Others" ("involuntary non-constitutive people"). Awareness of the unjustified privileges of certain collectives, with the individual members of the B\&H societies' animosity increases towards "Otherness" and "Diversity", which does not achieve the stability of $\mathrm{BiH}$ (which should represent the real goal of consociational democratic authority), rather it strengthens the centrifugal forces which contribute to the destabilization and disintegration of Bosnian society. 


\section{CONCLUSION}

An unfinished process of implementation of the Dayton Agreement and, in particular Annex 4 (the Constitution of $\mathrm{B} \& \mathrm{H})$, whose provisions permit discrimination against the citizens of Bosnia and Herzegovina (the impossibility of the realization of the principle of equality in the exercise of universal suffrage); inconsistent and incomplete implementation of Annex 7 (Agreement on Refugees and Displaced Persons), which "cemented" aggression caused division among ethnic communities, as well as the non-application of the Decision of the Constitutional Court contributes and is conducive to further segmentation of Bosnian society.

The future of B\&H in any case should not lie in the concept of separatism of ethnic communities, which is in collision with centuries of diverse coexistence and mutual respect for different religions and traditions, as well as modern European ideas that promote transnational political, economic and cultural cooperation.

The future of Bosnia and Herzegovina, therefore, definitely is not in the ethnic territorialization or in the further implementation of the "pure" model of consociational democracy, nor is the future of Bosnia and Herzegovina in implementing the principle of "pure" bourgeois democracy that in itself conceals intention to impose sameness of the largest nation. On the contrary, the future of Bosnia and Herzegovina must be in the Bosnian model, resulting in a long historical process of peaceful coexistence of different religions and ethnic communities. By applying the principles of Bosnian model, in which citizens are the subject of sovereignty, to strengthen state institutions and to build a strong and stable B\&H society in which all citizens and all social groups are equal before the law, while not ignoring differences arising from "the Otherness".

Applying the Bosnian model of democratic authority is a precondition for the stabilization of $\mathrm{B} \& \mathrm{H}$ society. Specifically, we believe that the B\&H society and the state must be organized in such a way that representatives of all "social segments" accept Bosnia and Herzegovina as their primary homeland. Representatives of all "segments of society" must be aware of the fact that neither has a monopoly over Bosnian state ter- ritory and history. Bosnia and Herzegovina must be based on the idea that she is the only homeland of Bosniaks, Bosnian Croats and Bosnian Serbs as well as all existing ethnic minorities.

The key to success is to promote the stability of the Bosnian state and society it is necessary to work on building mutual trust among b\&h population. The process of building trust among the members of different collectives will not be an easy process, however it is much easier to establish trust among the "masses that constitute the segments" rather than among the representatives of the elite "social segment" who would not be guided by the sense of commitment to preserve the unity of $\mathrm{B} \& \mathrm{H}$ and its democratic regime.

\section{REFERENCES}

Andeweg, B.R. (2000). Consociational democracy, Annual Reviews Political Science

Bohn, D. E. (1980). Consociational Democracy and the Case of Switzerland, Journal of Politics, 42 (1)

Ibrahimagić, O. (2008). Pledoaje za ustavne promjene u Bosni $i$ Hercegovini, Sarajevo: Oslobođenje - Pogledi

Kasapović, M. (2005). Bosna i Hercegovina - podijeljeno društvo i nestabilna država. Zagreb: NIZ Politička kultura

Kovač, N. (2006). Parcijalne reforme ustava vode ka definitivnoj legalizaciji podjele Bosne $i$ Hercegovine. Oslobođenje, Pogled

Lavić, S. (2006). Mit o «tri odvojene sobe» u Bosni i Hercegovini. (u svome osvrtu na ideje konsocijacije bh. društva $i$ države Mirjane Kasapović), Oslobođenje - Pogled

Malcolm, N. (1995). Povijest Bosne - kratki pregled. Erasmus Gilda, Zagreb- Sarajevo: Novi Liber

Miraščić, Dž. (2009). Bosanski model demokratske vlasti. Tuzla: NUB "Derviš Sušić", Tuzla, 2009.

Miraščić, Dž. (2012). Država nacija u multikulturnom društvu. Sarajevo: JP NIO "Službeni list BiH"

Mirić, J. (1996). Demokracija u postkomunističkim društvima. Zagreb: Prosvjeta

Mujkić, A. (2006). Da li je narod «prirodna vrsta» - Bosna i Hercegovina između etničke i etičke jednakosti. STATUS - magazin za političku kulturu i društvena pitanja, 9

Reilly, B. (2002). Electoral Systems for Divided Societies. Journal of Democracy, 13(2)

Stojanović, N. (2007). Konsocijacija - Švajcarska $i$ Bosna $i$ Hercegovina, Pregled - Časopis za društvena pitanja, LXXXVII, 3-4. Sarajevo

Trnka, K. (2006). Ustavno pravo, Drugo izmijenjeno i dopunjeno izdanje. Sarajevo: Fakultet za javnu upravu

Vlaisavljević, U. (2006). Etnopolitika i građanstvo. Mostar: Dijalog 